\title{
Precautionary Principles of the Circulation of Hazardous Chemicals as an Effort to Combat the Crime of Terrorism
}

\author{
Dani Teguh Wibowo ${ }^{1} \quad$ Made Warka $^{2} \quad$ Slamet Suhartono $^{2} \quad$ Otto Yudianto $^{2}$ \\ 1.Doctorate of Law Candidate at Law Faculty of 17 Agustus 1945 University of Surabaya, Indonesia \\ 2.Lecture of Law Faculty of 17 Agustus 1945 University of Surabaya, Indonesia
}

\begin{abstract}
The title of this article is the Precautionary Principles of the Circulation of Hazardous Chemicals as an Effort to Combat the Crime of Terrorism. This article base on research discusses about 1) What are the characteristics of the Crime of Terrorism using hazardous chemicals. 2) How is the principle of prudence in the distribution of hazardous chemicals as an effort to overcome criminal acts of terrorism. The two problem formulations were analyzed using normative legal research methods using the theory of legal objectives, the theory of criminal policy and the theory of legal protection. The research was conducted through several approaches, namely the statutory approach, the philosophical approach, the conceptual approach and the comparative approach.The transformation of terrorism uses hazardous chemicals as precursors of Improvised Explosive Devices (IED). The use of hazardous chemicals and the development of science makes the types of IEDs formed apart from high explosives (HEs IEDs), also found weapons of mass destruction (WMD) such as radioactive weapons. (Radio Active Material Weapons) and chemicals weapons (Chemicals Weapons). The transformation of terrorism will cause death, morbidity, onset in mass numbers and affect future generations. The right to life is irreversible which requires a special pro-active effort. Active law enforcement and establish an early warning system in the field of distribution of hazardous chemicals.To establish an early warning system in the field of hazardous chemicals, it is necessary to apply the precautionary principle. The application of the precautionary principle is due to the fact that protected legal interests are irreversible rights, the many related interests related to hazardous chemicals and the transformation of terrorism make the dynamics increasingly complex which at a certain point requires correct and appropriate decisions. The application of the precautionary principle requires administrative sanctions as a form of guidance and criminal sanctions for certain violations.
\end{abstract}

Keywords: hazardous chemicals, terrorism, precautionary principle

DOI: $10.7176 / \mathrm{JLPG} / 116-01$

Publication date: December $31^{\text {st }} 2021$

\section{Introduction}

The aim of the State of Indonesia as written in the Constitution of Republic Indonesia Year 1945 is to protect the entire people of Indonesia and Indonesian nation or social defense. Furthermore, the purpose of the state is also to develop social welfare and to educate the people, as well as to participate in the implementation of world's order based on the independency, eternal peace and social welfare.

However, the growth of terrorism could be an obstacle to incarnate nation's goal. Terrorism is an evil crime which used violence or threat to create terror or fear of massive victims in order to achieve its main goal that became the motive of terrorism. To this time, there is no universal definition of terrorism, United Nation Office on Drugs and Crime (UNODC) concerning to the prevention of terrorism defined terrorism as"a strategy of violence designed to instill terror in a segment of society in order to achieve some ulterior purposes." 1

In achieving its main goal, terrorism has always done some transformations. One of them is the usage of hazardous chemicals as explosive precursors of invented weapon known as Improvised Explosive Device (IED) or homemade bombs. The use of hazardous chemicals as explosive material has created the High Explosives Improvised Explosive Device (HEs IED) and Weapon of Mass Destruction (WMD) such as Radio Active Material Weapons and Chemicals Weapons. These three types of IEDs had been used in some terrorism attack in several countries including Indonesia.

The development of hazardous chemicals used as explosive IED is not accompanied by law reform to regulate and control the usage of hazardous chemicals which had been used by terrorists. At this time, the hazardous chemicals are regulated by several laws and regulations that create legal vacuity since the practical needs and the availability of positive law are not equal. The countermeasure of terrorism required a behavioral standard in the field of hazardous chemicals circulation and the cooperation of the entire elements of society to create an early warning system. The early warning system in the field of hazardous chemicals circulation is essential since it is the last safety guard of terrorism attack.

The transformation of terrorism using hazardous chemicals as weapons to perform a crime would create new crimes or trend crimes if it was not accompanied by legal development. According to Slamet Suhartono, this

\footnotetext{
${ }^{1}$ Shidarta and Jufrina, 2014, Legal Antinomy Pendulum; Antology 70 Years of Valereine J.L Kriekhoff, Genta Publisihing, Yogyakarta, p.278
} 
condition is a vacuity of legal positive norms. "The vacuity of legal positive norms was caused by the imbalance between practical needs and the availability of positive law." ${ }^{1}$ The valid legal positive norms that regulated supervision and control of hazardous chemicals was formed to solve problem dimensions that differed from explosive problem dimension. Different dimensions had made the valid positive legal norm showing inequality when compared to transformation of terrorism.

\section{Statement of Problems}

According to the background above, the problem was formulated as follows: (1) Characteristics of terrorism crime in Indonesia using hazardous chemicals, (2) Precautionary principle in the distribution of hazardous chemicals as an effort to combat terrorism. The purpose to be achieved in this dissertation research are: (1) To analyze and find the characteristics of terrorism crime using hazardous chemicals. (2) To find precautionary principles in the distribution of hazardous chemicals as an effort to combat terrorism crime.

\section{Research Methods and Approaches}

This study is a legal normative research that put law as a building of norm system. The intended norm system is on the foundation, norms, rules of legislation, court ruling, doctrinal agreement (teachings)." "Legal study was conducted to break the legal issue faced." ${ }^{3}$ Legal issue in this study is the precautionary principle of hazardous chemicals distribution in the countermeasure of terrorism crime.

Theoretical bases used in this study are: Legal Purpose Theory, Legal Protection theory and Criminal Policy Theory. The approaches used in this study are: statute approach, conceptual approach, comparative approach and philosophical approach

\section{Discussion}

\section{Characteristics of Terrorism Crime in Indonesia Using Hazardous Chemicals}

The type of weapons produced from the characteristic of terrorism crime using hazardous chemicals are HEs and WMD. The use of hazardous chemicals as explosive IED corresponded to the definition of explosives in Emergency Law of Republic Indonesia Number 12 Year 1951 on Alteration of "Ordonnantietijdelijke Bijzondere Strafbepalingen" (STBL. 1948 Number 17) and Constitution of Republic Indonesia Formerly Number 8 Year 1948 (Arms Emergency Law) were categorized as explosievemengsels. The development in using hazardous chemicals as WMD fitted in with the definition of WMD resulting from the committee formed by the United Nations in 1948. Both types of weapons had made terrorism crime more dangerous as there were more deaths, injuries and morbidity and on top of that it would affect the next generation.

In the context of creating social defense, advancing social welfare and educating people's life, as well as participating in the implementation of world order based on independency, eternal peace and social welfare as legal aspiration, it is necessary to have philosophical thought about justice. Concerned with justice, Radbruch stated "The idea of the law we found in justice; and we determined the essence of justice, of distributive justice, as equality: equal treatment of equal, and correspondingly unequal treatment of different, men and relationships." "Justice according to Radbruch is a proportional distributive justice that became the values which formed law and evaluation value to legal reality. Evaluation towards legal reality and applicable law through legal ideals had the meaning of whether legal reality is in accordance with legal ideals. The result of the evaluation of legal ideals against legal reality is whether legal changes are necessary to provide justice or not. The evaluation of legal ideals had been done considering the existence of dynamic human life so sometimes the distributions of rights and obligations were not in accordance with the development of humans' problem in life.

Furthermore, Radbruch also said "From the validity of law for the together life of men, their mutual relations, there follows that its contents must be to establish legal relations, and as their elements, legal duties and legal rights, subjective rights." ${ }^{5}$ Radbruch then continued "rights and duties are not conceivable without subjects to whom they belong, nor without objects to which they relate." According to Radbruch's opinion, it could be meant that law was formed to solve human's problem in life so that legal contents divided rights, obligations and subjective rights by considering the surrounding condition and relation. The surrounding relations are first is the legal subject that owns it and the second is the related object.

Legal subject that owns it is the community members who related to the right to life and the businessmen

\footnotetext{
${ }^{1}$ Slamet Suhartono, 2020, Positive Law Problematic Application and Its Theoritical Solution, DIH; Law Journal Volume 15 Number 2 August 2019, p. 205

${ }^{2}$ Mukti Fajar and Yulianto Akhmad, 2013, Dualism of Normative and Empirical Legal Research, Second Print out, Pustaka Pelajar,Yogyakarta, p.34

${ }^{3}$ Peter Mahmud Marzuki, 2016, Legal Research, Revised Edition, Print out 12, Kencana, Jakarta, p. 60

${ }^{4}$ Kurt Wilk, 1950, 20Th Century Legal Philosophy Series: Vol. IV: The Legal Philosophies Of Lask, Radbruch, And Dabin, Harvard

University Press, USA, New York, p. 107.

${ }^{5}$ Ibid, p. 77.

${ }^{6}$ Ibid, p. 78
} 
who related to the right of performing business. The rights to life is fundamental right and a priori to other rights along with the rights that cannot be recovered. The interpretation of right to life consists of two aspects which are rights of living and "existence of certain practices potentially and factually implied to violation of right to life although the practice is legitimate based on specific perspective (so it was not an arbitrary deprivation of live)."1

The right to life is an important component of independence since freedom and other rights adhered to the right to life. Without life, the right of freedom and other rights would be insignificant. Some practices in humans' life had potency and implication to the violation of the right to life both in purpose or not. The Law of Republic Indonesia Number 39 Year 1999 on Human Rights (Human Rights Act) Article 70 stated that the restriction of rights through constitution to assure admission and admiration towards Human Rights along with the basic freedom of others, decency, public order and national interests.

The word assurance has the meaning of a legal order to the state since in Article 71 of Human Rights Act provides an obligation to the government to protect the human rights of citizens. According to Hesti Armiwulan Sochmawardiah, the word assured that "assurance in law terminology is not limited on the protection of state apparatus toward individuals but also should be secured in laws and regulations." 2 Both ways of assurance should be done simultaneously so the assurance of human rights protection could be implemented. Law was formed to protect human rights equivalently through laws and regulations that had been formed by the state.

Government as the interpretation of state had obligation to assure the protection of both rights proportionally. In order to ensure that there were two conflicting legal interests, according to Dworkin "the values underlying the formulation" 3 must be considered. The rights to be non derogable rights is the rights that cannot be reduced or restricted as formulated in Constitution of Republic Indonesia Year 1945 Article 28 I, while the right to perform business is a right that can be restricted. The restriction of rights in performing business could be done for public interest purpose by seeing another connected object.

Connected objects as the first were hazardous chemicals and crime of terrorism. Hazardous chemicals that were used by terrorists fundamentally was inherently dangerous material. Inherently dangerous is "(Of an

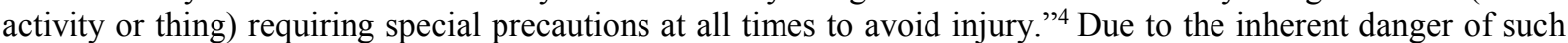
hazard, knowledge and experience are required in the use of hazardous chemicals. Government had tried to prevent the misuse of hazardous chemicals by stipulating forbidden or restricted chemicals and requiring labels which described the danger of material and the usage instruction.

Regulation concerned with hazardous chemicals could not stop the misuse of hazardous chemicals by businessmen and it turned out to be used by terrorists. The use of hazardous chemicals by terrorist has some purposes:

a Hazardous chemicals used by terrorist has different purpose to other hazardous chemicals. Hazardous chemicals used by terrorist can be categorized as a part of explosive weapon. Any activity related to explosive is abnormal activity and has dangerous risk, in legal terminology it is called abnormally dangerous activity. Abnormally dangerous activity is "an undertaking that necessarily carries with it a significant risk of serious harm even if reasonable care is used, and for which the actor may face strict liability for any harm caused." 5

b There is an improved quality, formerly the misuse of hazardous chemicals is aimed to gain economic value has now become to murder or hurt other people.

Due to the disparity of both connected objects, a regulation of hazardous chemicals which rests on the reduction of materials or hazardous chemicals, activities and people is needed. Some countries such as United Kingdom, Canada, Singapore, Australia and Netherlands had made alteration in hazardous chemicals regulation as explosive precursors. The regulation of hazardous chemicals circulation which rests on individual characters and abilities which related to explosive precursors. The restriction of explosive precursor concentrate value that could be distributed and the effort to minimalize risk prevention such as risk management.

The last, there is reinforcement through criminalization of several violations of the circulation of explosive precursors which based on action. If we examined the sanction on laws and regulations which organized hazardous chemicals, currently is still partial, which relied on the consequences in their respective fields. The classification of hazardous chemicals is moving and depleted goods when it is used, which was a difficult classification to control and supervise against violation if the sanction norm is still partial and based on consequences. Legal interest is the right to life that could not be recovered needs sanction norm that relied on action.

\footnotetext{
${ }^{1}$ Titon Slamet Kurnia, 2015, Interprestation of Human Rights by The Constitutional Court of Republic Indonesia; The Jimly Court 20032008, Mandar Maju, Bandung, p. 145

${ }^{2}$ Hesti Armiwulan Sochmawardiah, 2013, Racial Discrimination in Human Rights Act; Comparative Study of Discrimination Against Chinese Ethnicity, Genta Publishing Yogyakarta, p. 58

${ }^{3}$ Achmad Ali, 2008, Revealing the Veil of Law, 3rd Print, Ghalia, Bogor, p.179.

${ }^{4}$ Bryan A Garner, 1999, Black's Law Dictionary, Seventh Edition, West Group, St. Paul, Minn, p.451.

${ }^{5}$ Bryan A Garner, Op., Cit, p.5
} 
The disparity of the two connected objects had formed "Imbalance between legal practice needs and availability of positive law." According to Slamet Suhartono, that condition is a legal vacuity which indicates unideal conditions. Based on Radbruch's opinion, ideal condition is "either the application or observance of a law, or the law itself" Moreover, Radbruch stated "There can be laws that are so unjust and so socially harmful that validity, indeed legal character itself, must be denied them." ${ }^{\prime 3}$ Both of Radbruch's opinions that law was formed to create ideal condition so that it had relation between law and dimensions of problem, in other words the law adjusted to the dimensions of problem in human's life.

Currently, the regulation of hazardous chemicals is not appropriate with the development of human's dimensions of problem and jeopardize human life. At this time, the dimensions of problem of hazardous chemicals is linked to explosives, in such a way, considering the right to life as secured legal interest, laws and regulations as well as an effort to minimize the risk are needed. Interest that linked to the right to life is connected with the facts and moral problems. Morally, murdering and letting death are the same since the life of everyone is equally essential and there is no external criterion which caused their interests are not equal. Based on the findings and theoretical analysis, it is suggested to alter the regulation of hazardous chemicals in one law and regulation which is in accordance with the existing dimensions of problem namely the Arms Emergency Law.

\section{Precautionary Principles in the Circulation of Hazardous Chemicals as an Effort to Combat Crime of Terrorism}

Crime of terrorism is an organized crime and always transforms following technology development and adapts to the condition for the success of its activity. Crime of terrorism has done transformation in entire fields which are organization, actors, activities and facilities. Transformation of activities had been done by changing indoctrination patterns, funding, training and planning the crime of terrorism which optimized the use of technology. Transformation of facilities is the alteration of weapons used which led into the use of hazardous chemicals as HEs and WMD. Transformation of actors is the change of the terrorism perpetrators that used to be done by men has now changed into women, children and even a family.

Crime of terrorism is a part of humans' problem in their life which required solution and prevention to create social order. According to Mark Ancel, the concept of crime prevention policy is "criminal policy is the rational organization of the control of crime by society. Criminal policy is a rational action of an organization, in this case is the country, to prevent dangerous activities and to take actions against those who caused harm. G.P Hoefnagel as quoted by Otto Yudianto, stated that crime prevention policy could be pursued using several methods, viz.:

1. Criminal law aplication;

2. Prevention without punishment; and

3. Influencing views of society on crime and punishment or mass media. ${ }^{4}$

The concept of crime of terrorism based on the Law of Republic Indonesia Number 5 Year 2018 concerning Amendment to Law Number 15 Year 2003 about the Stipulation of Government Regulations in lieu of Law Number 1 Year 2002 on Eradication of Criminal Acts of Terrorism into Law (Crime of Terrorism Act) is anticipatory and proactive steps which relied on the prudence to provide a balance legal protection among the interests of the state, the interests of victims and the terrorists as well. Proactive and anticipatory steps in order to protect the interests of the state and victims had been manifested in the prevention concepts of three aspects. The prevention of crime of terrorism on the three aspects are indoctrination aspect, funding and facility aspect.

Criminal policy which had been done by the state in the aspect of prevention was only applied on the two aspects viz. indoctrination and funding. Prevention of the two aspects is through the integration of penal and non-penal efforts. However, the integrated effort between penal and non-penal had not been done for the aspects of facility. Jointly efforts should be done on the three aspects in the preparation field, so it could cover the weakness in their respective fields.

The aspect of facilities in the distribution of hazardous chemicals is the final line in the field of preparation which required special efforts in the field of goods, places, activities and people. The use of hazardous chemicals by terrorists as explosives had made the activities that related to hazardous chemicals required specific efforts to minimize the risks toward goods, activities and the humans who wanted to murder and injure other humans.

One of the efforts to minimize rational risks and had been done on several fields is the precautionary

\footnotetext{
${ }^{1}$ Slamet Suhartono, 2020, Positive Law Problematic Application and Its Theoritical Solution, DIH; Law Journal Volume 15 Number 2 August 2019, p. 205

${ }^{2}$ Kurt Wilk, Op., Cit,, p. 74

${ }^{3}$ Gustav Radbruch, 2006, Five Minutes Of Legal Philosophy (1945); Translated By Bonnie Litschewski Paulson And Stanley L. Paulson, Oxford Journal of Legal Studies, Vol. 26, No. 1 (2006), pp. 13-15, p. 26

${ }^{4}$ Otto Yudianto, 2015, Formulative Policy On Life Imprisonment in the Context of Reforming Indonesia Criminal Law, Brilliant, Surabaya, p.42
} 
principle. The concept and terminology of prudence according to Aristotles is "if he/she calculated the entire things carefully in the relation with the valuable purpose that could not be achieved by applied science or technology or art. Therefore, generally someone who had practical policy is the one who had the ability to examine."1 Cicero defined it as "a way of thinking, speaking, acting, and judging in the midst of complexity and change." $"$

The statements of the two philosophers made reference to the demarcation of the definition of prudence by Robert Hariman viz. " “...with respect to three essential conditions of political choice: contingency, plurality, and praxis." ${ }^{3}$ Contingency is based on the uncertainty of human world because of the complexity that had been created by desire, opportunity and high interdependence among the entire variables that influenced actions. Plurality is based on the condition with a lot of autonomous parts and interrelated with the conclusive decision. Those parts are relevant to various relations such as desires, collective and individual interests, since prudence is connected with various potential perspectives. Praxis is based on the facts identification that at some certain points, wisdom must be translated into action.

The three conditions were the signs or boundaries of the needs for precautionary measures. It is necessary to take precautionary measures for the circulation of hazardous chemicals due to the following conditions:

a The secured legal interest is the rights that could not be recovered;

b Transformation of terrorism created dynamic condition and uncertainty so that on some specific points decision is needed; and

c Hazardous chemicals are chemicals that have many connection especially in industrial field. The development of dimensional problem of hazardous chemicals and crime of terrorism affecting humans' life such as, economy, psychosocial and nation disintegration if there was misuse and violation of hazardous chemicals distribution.

Precautionary principles on the distribution of hazardous chemicals is to minimize or eliminate the risks to people, materials, places as well as preemptive, preventive and repressive activities. The efforts taken through the precautionary principles still have to observe legal protection of the citizens. According to Phillipus M. Hadjon, legal protection towards the citizens contains 2 (two) means of preventive legal protection and repressive legal protection. ${ }^{4}$

Preventive legal protection based on citizens' opportunity to get involved before the government made a decision in the form of opinion, information and suggestion before the decision is made. That process was expected to provide information in different perception so the decision had gone through comprehensive consideration process. Repressive legal protection is protection that was done through the judiciary to resolve dispute. Repressive legal protection at the micro level referred to procedural law system or formal law. Repressive legal protection at the macro level is how the law provides protection in the form of judicial system that is in accordance with the existing problem. Complexity of problems in human life often caused a condition of problem that was not only in one jurisdiction of judicial system. This condition required a solution that could provide justice and legal certainty against the perpetrators.

The efforts of applying precautionary principles in the distribution of hazardous chemicals as an effort to combat crime of terrorism are through: First, preemptive effort. According to Ivo H. Daalder "there was widespread agreement that force-even when used preemptively-can be an appropriate response to the terrorist threat." Preemptive means precaution which was done previously by intervention and inhibition intended to eliminate the intention of the terrorists who used hazardous chemicals as IED. Preemptive efforts was done by setting hazardous chemicals as explosive precursors and limiting the concentration of hazardous chemicals that had been distributed.

Second, preventive effort through licensing which relied on character, ability or capacity and security. According to Hariman, the reasoning processes in prudence are "the first is deliberating ...the second is making a judgement about the results of .... third, state consists in executing the results of deliberation and decision." 6 The three reasoning processes required factual and relevant information so in collecting information about granting of permits could be through: ability and feasibility test, signature of approval as close partners, periodic report, providing valid personal information and risk management plans for the safety of place, activity, etc.

Meanwhile, for the businessmen is to make an attempt of risk management, stock management, trying to communicate with the customers, Know Your Customers, inspecting the customers through hazardous chemicals business community and also a means of assistance from the government in the form of communication network

\footnotetext{
${ }^{1}$ Aristoteles, 2004, Nichomachean Ethics, Translated by Embun Kenyowati, Teraju, Jakarta, .p.148

${ }^{2}$ Robert Hariman, 2003, Prudence Classical Virtue; Post Modern Practice, Pennsylvania State University Press, Usa, Pennsylvania, p.294

${ }^{3}$ Ibid., p. 298

${ }^{4}$ Philipus M. Hadjon, 1987, Legal Protection For the Citizen in Indonesia, Bina Ilmu, Surabaya, p. 2

${ }^{5}$ Ivo H. Daalder, 2007, Beyond Preemption; Force And Legitimacy In A Changing World, Brookings Institution Press, Usa, Washington, D.C, p. 2

${ }^{6}$ Robert Hariman, Op., Cit, p.318
} 
is needed to find out the last users who hold the license.

Lastly, the penal effort which is through criminalization effort of several acts of violating the circulation of hazardous chemicals with criminal sanction or fines. Criminal prosecution was given to the perpetrators or license holder or the corporation. Punishment was given to the license holder considering one of the licensing processes which is ability and feasibility test that showed the permit of the activity is also related to personal characters and quality of the applicant. Based on the findings and theoretical analysis, it is proposed to apply precautionary principles in the circulation of hazardous chemicals as an effort to combat the crime of terrorism.

\section{CONCLUSION}

1. The Characteristic of terrorism crime using hazardous chemicals is a part of terrorism transformation in the field of facility that is device or weapon used in terrorism attack. The use of hazardous chemicals as weapon by terrorists has characteristics as follows: (1) Type of weapon that was made was high explosive (HEs) and weapon of mass destruction (WMD). (2) Bring consequences to humans in form of morbidity or mortality in large numbers, onset in the future and can affect the next generation. (3) The act of violating hazardous chemical distribution is an act of assisting Terrorism Crime and also violation to the right to life of community members. The use of hazardous chemicals by terrorists had caused the object related to the existing statutory arrangements different viz.: First, the hazardous chemicals is a part of explosive weapons. Second, related characteristic of crime which is the intention of terrorists to injure and murder other people.

2. Transformation of terrorism using hazardous chemicals as weapon has made the condition of hazardous chemicals distribution fit in with the limitation of applied precautionary principles which are: (1) Protected legal interest is an interest that cannot be recovered that is the right to life. (2) The number of relation of humans life interests to the use of hazardous chemicals. (3) Dynamic transformation of terrorism has caused an uncertain condition of activities which relate to hazardous chemicals so in specific points, a decision to perform an act is needed.

\section{SUGGESTION}

To the Legislative, to make an alteration of Arms Emergency Act as an effort to settle the growth of hazardous chemicals problem that is used by terrorist as explosive materials and to define a regulation of precautionary principles in the distribution of hazardous chemicals to eliminate and minimalize the risk to people, goods, places and activities.

\section{References}

Shidarta and Jufrina, 2014, Legal Antinomy Pendulum; Antology 70 Years of Valereine J.L Kriekhoff, Genta Publisihing, Yogyakarta.

Slamet Suhartono, 2020, Positive Law Problematic Application and Its Theoritical Solution, DIH; Law Journal Volume 15 Number 2 August 2019.

Mukti Fajar and Yulianto Akhmad, 2013, Dualism of Normative and Empirical Legal Research, Second Print out, Pustaka Pelajar, Yogyakarta.

Peter Mahmud Marzuki, 2016, Legal Research, Revised Edition, Print out 12, Kencana, Jakarta.

Kurt Wilk, 1950, 20Th Century Legal Philosophy Series: Vol. IV: The Legal Philosophies Of Lask, Radbruch, And Dabin, Harvard University Press, USA, New York.

Titon Slamet Kurnia, 2015, Interprestation of Human Rights by The Constitutional Court of Konstitusi Republic Indonesia; The Jimly Court 2003-2008, Mandar Maju, Bandung.

Hesti Armiwulan Sochmawardiah, 2013, Racial Discrimination in Human Rights Act; Comparative Study of Discrimination Against Chinese Ethnicity, Genta Publishing Yogyakarta.

Achmad Ali, 2008, Revealing the Veil of Law, $3^{\text {rd }}$ Print, Ghalia, Bogor.

Garner, Bryan A., 1999, Black's Law Dictionary, Seventh Edition, West Group, St. Paul, Minn.

Slamet Suhartono, 2020, Positive Law Problematic Application and Its Theoritical Solution, DIH; Law Journal Volume 15 Number 2 August 2019.

Gustav Radbruch, 2006, Five Minutes Of Legal Philosophy (1945); Translated By Bonnie Litschewski Paulson And Stanley L. Paulson, Oxford Journal of Legal Studies, Vol. 26, No. 1 (2006), pp. 13-15.

Otto Yudianto, 2015, Formulative Policy On Life Imprisonment in the Context of Reforming Indonesia Criminal Law, Brilliant, Surabaya.

Aristoteles, 2004, Nichomachean Ethics, Translated by Embun Kenyowati, Teraju, Jakarta.

Robert Hariman, 2003, Prudence Classical Virtue; Post Modern Practice, Pennsylvania State University Press, Usa, Pennsylvania.

Philipus M. Hadjon, 1987, Legal Protection For the Citizen in Indonesia, Bina Ilmu, Surabaya.

Ivo H. Daalder, 2007, Beyond Preemption; Force And Legitimacy In A Changing World, Brookings Institution Press, USA, Washington, D.C. 